Received 23.11.2015 Reviewed 20.01.2016 Accepted 13.02 .2016

A - study design

B - data collection

C - statistical analysis

D - data interpretation

$\mathbf{E}$ - manuscript preparation

F - literature search

\section{Assessment of the effect of reactive materials on the content of selected elements in Indian mustard grown in Cu-contaminated soils}

\section{Maja RADZIEMSKA ${ }^{\text {1) ABDEF }}$, JerZy JEZNACH ${ }^{1)}$ DE Zbigniew MAZUR ${ }^{\text {BCF }}$, Joanna FRONCZYK ${ }^{1) \text { BF }}$, Ayla BILGIN ${ }^{3) ~ F}$}

${ }^{1)}$ Warsaw University of Life Sciences - SGGW, Faculty of Civil and Environmental Engineering, Poland; e-mail: maja_radziemska@sggw.pl; jerzy_jeznach@sggw.pl; joanna_fronczyk@sggw.pl

${ }^{2)}$ University of Warmia and Mazury in Olsztyn, Faculty of Environmental Management and Agriculture, Poland; e-mail: zbigniew.mazur@uwm.edu.pl

3) Artvin Coruh University, Faculty of Engineering, Seyitler Campus 08000 Artvin, Turkey; e-mail: ayla.bilgin@artvin.edu.tr

For citation: Radziemska M., Jeznach J., Mazur Z., Fronczyk J., Bilgin A. 2016. Assessment of the effect of reactive materials on the content of selected elements in Indian mustard grown in $\mathrm{Cu}$-contaminated soils. Journal of Water and Land Development. No. 28 p. 53-60.

\begin{abstract}
Zero-valent iron (ZVI) represent a promising agent for environmental remediation. The research was aimed to determine the influence of copper in doses of $0,80,150,300$, and $600 \mathrm{mg} \mathrm{Cu} \cdot \mathrm{kg}^{-1}$ of soil as well as ZVI, and lignite additives on the content of macroelements in the Indian mustard (Brassica juncea (L.) Czern.). The average accumulation of analyzing elements in Indian mustard grown in copper contaminated soil were found to follow the decreasing order $\mathrm{Mg}>\mathrm{Na}>\mathrm{P}>\mathrm{Ca}>\mathrm{K}>\mathrm{N}$. Soil contamination at $600 \mathrm{mg} \mathrm{Cu} \cdot \mathrm{kg}^{-1}$ of soil led to the highest increase in $\mathrm{P}, \mathrm{Mg}, \mathrm{N}$, and $\mathrm{Ca}$ content. The application of ZVI had a positive influence on the average phosphorus and potassium content of Indian mustard. Moreover, the application of ZVI and lignite had a positive influence on the average $\mathrm{Mg}$ and $\mathrm{Ca}$ content in the above-ground parts of Indian mustard. From the analyzed reactive materials, the application of lignite was shown to be the most effective resulting in the decrease in the average nitrogen and calcium content when compared to the control crop. Calcium content in plants from the control group, without the addition of zero-valent iron, and powered lignite (control), was positively correlated with increasing doses of copper.
\end{abstract}

Key words: Indian mustard, lignite, soil contamination, zero-valent iron (ZVI)

\section{INTRODUCTION}

The contamination of soils with heavy metals, including copper $(\mathrm{Cu})$, is a major problem for environmental quality worldwide [SANTANA et al. 2015]. In literature on the subject, the harmful effect of $\mathrm{Cu}$ has been well documented, especially in soils with a low pH [ZAHEER et al. 2015]. In Poland, the highest amounts of heavy metals released into the environment have been reported in the following voivode- ships: Dolnośląskie, Śląskie, Małopolskie, Mazowieckie, Łódzkie, Wielkopolskie. It is in these regions that we can find so-called "hot spots", characterized by the highest levels of heavy metal contamination in the country, which pose a huge danger to the environment.

According to the latest studies, the level of copper in the surface layers of soil in the protected zones fell within the range of 147 to $450 \mathrm{mg} \cdot \mathrm{kg}^{-1}$, which in the case of all trials exceeded the permissible level of 
copper for heavy soils, i.e. $100 \mathrm{mg} \cdot \mathrm{kg}^{-1}$. In terms of the level of soil contamination, as established by Institute of Soil Science and Plant Cultivation (IUNG) and accounting for the granulometric composition as well as the $\mathrm{pH}$ of soils, the 4 th level of contamination was noted in 4 regions (Biała, Pawłowice, Jaszków - in the northern part of the zone as well as in Liniki south of the foundry), which indicates severe contamination of soil with copper; only in the Smokowice region was level III, signifying a medium contamination of soil with $\mathrm{Cu}$, reported. Despite recultivation processes, such as calcification or forestation, the problem of excessive copper mobility has still not been eliminated. This necessitates finding the most optimal methods of remediation based on the immobilization (stabilization) of $\mathrm{Cu}$ in soil.

Zero-valent iron (ZVI) is an environmentally benign material that has been widely used as a reducing agent to treat environmental pollutants, i.e. in wastewater, groundwater, and soils [FRONCZYK, PAWLUK 2014; FJORDBøGE et al. 2012]. Due to its large surface area and high number of active sites, zero-valent iron (ZVI) enhances the efficiency of remediation [CALDERON, FULLANA 2015]. Promising results of pplying the sorption and reduction properties of zero-valent iron (ZVI) and products of its oxidization as an effective sorbent or material for the remediation waters or soils contaminated by heavy metals have been reported by authors, i.e. CUNDY et al. [2008], HWANG et al. [2016], ZHANG et al. [2003]. Iron nanoparticles (nZVI) are applied directly to the soil as a suspension or with the addition of a dispergent which prevents the agglomeration of particles and increases their reactivity $[\mathrm{XU}$, ZHAO 2007]. Zero-valent iron (ZVI) is very effective in transforming and detoxicating many contaminants, e.g. chlorinated solvents, organochlorine pesticides and polychlorinated biphenyls. In soil, it binds cation contaminants, such as: $\mathrm{Pb}^{2+}, \mathrm{Cu}^{2+}, \mathrm{Ni}^{2+}, \mathrm{Cr}^{6+}$, and $\mathrm{As}^{3+}$ [ALOWITZ, SCHERER 2002]. Iron in the form of $\mathrm{Fe}^{+2}$ as well as metallic iron reduce and lower the toxicity of Cr(VI) in ground water and soil [PULS et al. 1999].

The efficiency of the sorption of contaminants is dependent on the composition of the liquid phase of the soil-solution system, as well as the presence of ions competing with organic matter [JIN et al. 2015]. A decrease of copper mobility can be achieved by applying organic materials characterized by high sorption capacity, such as compost and lignite, to the soil. Studies presented by KWIATKOWSKA et al. [2006] have shown that the fertilization of soils with lignite causes remarkable enrichment of soil in organic matter, as well as increasing the sorption and water capacity of soils. However, not all aspects nor long-term effects of applying metallic iron to soil are fully known, which stems from the complexity of chemical and microbiological processes [MASCIANGIOLI, ZHANG 2003].

The research objective of this work was to investigate the effect of zero-valent iron (ZVI) and lignite on the efficiency of the applied phytoremediation technique for the removal of copper from soils involving the use of Indian mustard (Fig. 1).

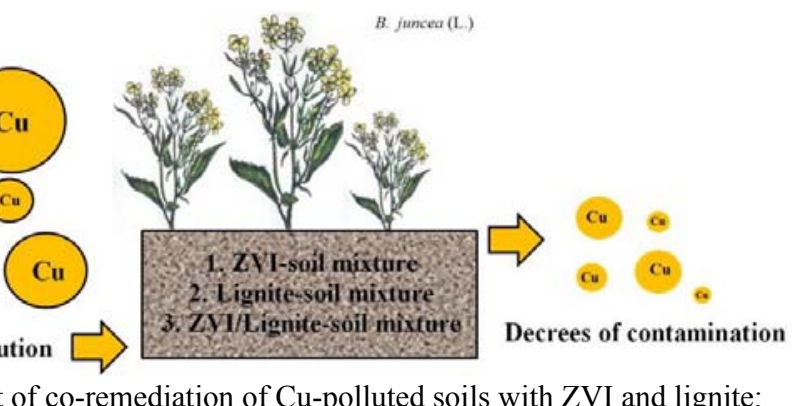

mediation of $\mathrm{Cu}$-polluted soils with ZVI and lignite; source: own elaboration

\section{MATERIAL AND METHODS}

The impact of adding zero-valent iron (ZVI) and lignite to soil contaminated with copper $(\mathrm{Cu})$ on the content of selected elements in Indian mustard (Brassica juncea (L.) Czern.) was assessed under the conditions of a pot experiment in an acclimatized greenhouse. The experiment was arranged in a randomized block design, with two factors and fourfold replication. The first factor was the addition of increased doses of copper to soil $(0,80,150,300$, and 600 $\mathrm{mg} \cdot \mathrm{kg}^{-1}$ ) introduced in the form of chemically pure aqueous solutions of copper(II) chloride dihydrate $\left(\mathrm{CuCl}_{2} \cdot 2 \mathrm{H}_{2} \mathrm{O}\right)$. The second factor consisted the addition of two reactive materials, i.e. ZVI, lignite, and the mixture of $\mathrm{ZVI} /$ lignite $(3.0 \% \mathrm{w} / \mathrm{w})$. Soils without copper and reactive materials $(0.0 \%)$ were designated as the control. Uncontaminated soil for the experiment was collected from the humic horizon from the arable layer $(0-20 \mathrm{~cm})$ of farmland in the vicinity of

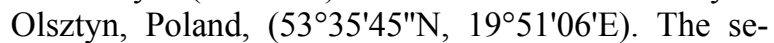
lected properties of the soil are shown in Table 1.

Polyethylene pots were filled with $9.5 \mathrm{~kg}$ of the air-dried soil sieved to $<1 \mathrm{~cm}$, and were maintained under natural day/night conditions; during the day (14 h), the air temperature was $26 \pm 3^{\circ} \mathrm{C}$ and approximately ten degrees lower $\left(16 \pm 2^{\circ} \mathrm{C}\right)$ at night $(10 \mathrm{~h})$. Soil was fertilized with a macro- and micronutrient fertilizer mixture $\left(\mathrm{g} \cdot \mathrm{kg}^{-1}\right)$ containing $\mathrm{N}-26 \%, \mathrm{~K}_{2} \mathrm{O}-$ $26 \%, \mathrm{~B}-0.013 \%, \mathrm{Cu}-0.025 \%, \mathrm{Fe}-0.05 \%, \mathrm{Mn}-$ $0.025 \%$, and Mo $-0.20 \%$. The plants were watered every other day with distilled water to $60 \%$ of the maximum water holding capacity of the soil by adding deionized water.

Nano zero-valent iron (ZVI) was purchased from iPutec GmbH \& Co. KG, Rheinfelden, Germany. Moreover, a surface area and porosity analyzer (ASAP 2020M Micromeritics, USA), scanning elect- 
Table 1. Physicochemical parameters of the experimental soil

\begin{tabular}{|l|r|}
\hline \multicolumn{1}{|c|}{ Parameter } & Value \\
\hline Soil chemical parameters & \\
- $\mathrm{pH}$ & 4.80 \\
- hydrolytic acidity, mmol $\cdot \mathrm{kg}^{-1}$ & 33.75 \\
- sum of exchangeable bases, $\mathrm{mmol} \cdot \mathrm{kg}^{-1}$ & 62.20 \\
- cation exchange capacity, $\mathrm{mmol} \cdot \mathrm{kg}^{-1}$ & 95.95 \\
- base saturation, \% & 64.80 \\
\hline Organic matter & \\
- organic carbon, $\mathrm{g} \cdot \mathrm{kg}^{-1}$ & 7.13 \\
- total $\mathrm{N}, \mathrm{g} \cdot \mathrm{kg}^{-1}$ & 1.04 \\
- carbon : nitrogen & 6.85 \\
- $\mathrm{N}-\mathrm{NH}_{4}{ }^{+}, \mathrm{mg} \cdot \mathrm{kg}^{-1}$ & 21.18 \\
- $\mathrm{N}-\mathrm{NO}_{3}{ }^{-}, \mathrm{mg} \cdot \mathrm{kg}^{-1}$ & 9.88 \\
\hline Grain size distribution, \% & \\
- fractions $2.0-0.05 \mathrm{~mm}$ & 86.6 \\
- fractions $0.05-0.002 \mathrm{~mm}$ & 11.2 \\
- fractions $0.002 \mathrm{~mm}$ & 2.2 \\
\hline Available forms, $\mathrm{mg} \cdot \mathrm{kg}^{-1}$ & \\
- phosphorous & 46.6 \\
- potassium & 8.2 \\
- magnesium & 33.9 \\
\hline
\end{tabular}

Source: own study.

ron microscope (SEM) images (FEG Quanta 250, USA), and X-ray diffraction (Philips X'Pert APD, Netherlands) spectra were used to detailed characterization of zero-valent iron (ZVI). Lignite sample came from Konin Brown Coal Basins (Poland). Scanning electron microscope (SEM) images of zero-valent iron (ZVI) and lignite are shown in Fig. 2.
Indian mustard of the Małopolska variety was the plant of choice for the experiment. The seeds of Indian mustard were obtained from an authorized Seed Production Centre in Olsztyn, Poland (OLZNAS-CN Sp. z o.o.). The plant density was set at 5 plants per pot and was picked following 98 days of vegetation in the flowering phase. In the laboratory, aboveground parts of Indian mustard were thoroughly rinsed first with tap water and then with deionized water to remove dust and soil particles. After oven drying $\left(60^{\circ} \mathrm{C}\right.$, $48 \mathrm{~h}$ ), the plants were weighed and before being powdered using an analytical mill (A 11 IKA, Germany), preceding the chemical analyses.

The plant samples were subjected to mineralization in condensed sulphuric acid (VI) with hydrogen peroxide. The content of the following elements was determined in the obtained extracts: total nitrogen content by Kjeldahl's distillation method [BREMNER 1965] after mineralization in concentrated sulphuric (VI) acid with hydrogen peroxide added as a catalyst; phosphorus $(\mathrm{P})$ - colorimetric analysis using the vanadium-molybdenum method [CAVELL 1955]; sodium $(\mathrm{Na})$, calcium $(\mathrm{Ca})$, potassium $(\mathrm{K})$ - atomic emission spectrometry - AES method [SZYSZKO 1982]; magnesium $(\mathrm{Mg})$ - atomic absorption spectrometry - AAS method [SZYSZKO 1982].

Before setting up the experiment, the following soil properties were determined: the grain size composition of the soil with the laser method using a Mastersizer $2000 \mathrm{~m}, \mathrm{pH}$ - determined by means of the

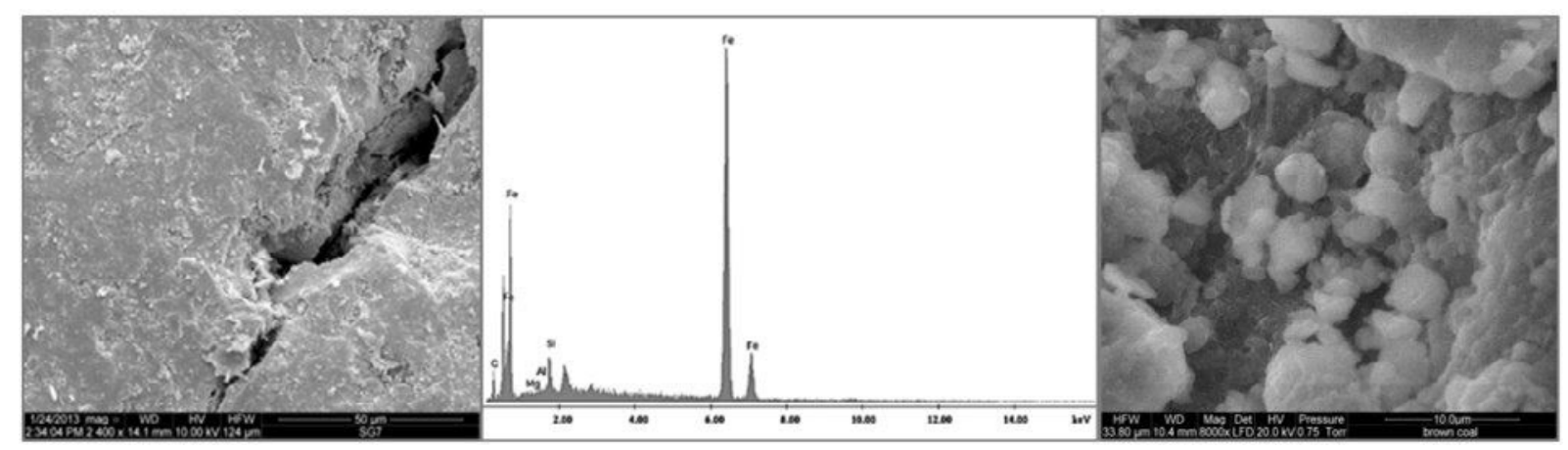

Fig. 2. The SEM images and EDX pattern of ZVI; SEM of lignite samples; source: own elaboration

potentiometric method using an aquatic solution of $\mathrm{KCl}$ at a concentration of $1 \mathrm{M} \mathrm{KCl} \cdot \mathrm{dm}^{-3}$ with a glass electrode and a Handylab pH/LF 12 pH meter (Schott, Germany), Standard Methods; hydrolytic acidity (HAC) by Kappen's method, the soil samples were treated with $0.5 \mathrm{M} \cdot \mathrm{dm}^{-3} \mathrm{Ca}$-acetate solution adjusted to $\mathrm{pH} 8.2$ in the ratio of $1: 2.5)$ [KLUTE 1996], total exchangeable bases (TEB-K $\mathrm{K}^{+} \mathrm{Na}^{+}, \mathrm{Ca}^{2+}$, and $\mathrm{Mg}^{2+}$ ) by Kappen's method through determining individual cations after extraction from the soil with $\mathrm{CH}_{3} \mathrm{COONH}_{4}$ [KLUTE 1996], cation exchange capacity (CEC) from the formula: $\mathrm{CEC}=\mathrm{HAC}+\mathrm{TEB}$ and percentage base saturation $(\mathrm{V})$ from the formula: $\mathrm{BS}$ $=100 \mathrm{TEB} / \mathrm{CEC}^{-1}$. Organic matter was determined according to Tiurin's method after the hot digestion of soil samples with $\mathrm{K}_{2} \mathrm{Cr}_{2} \mathrm{O}_{7}$ and $\mathrm{H}_{2} \mathrm{SO}_{4}$ in the presence of $\mathrm{Ag}_{2} \mathrm{SO}_{4}$ as a catalyst and the titration of $\mathrm{K}_{2} \mathrm{Cr}_{2} \mathrm{O}_{7}$ excess with $\mathrm{FeSO}_{4} /\left(\mathrm{NH}_{4}\right) 2 \mathrm{SO}_{4} \cdot 6 \mathrm{H}_{2} \mathrm{O}$ [MOCEK, DRZYMAŁA 2010]. Deionized water with a specific conductance of $0.055 \mu \mathrm{S} \cdot \mathrm{cm}^{-1}$ was used for the analyses.

Statistical analysis was performed using the software Statistica ver 10.0. Differences of means between treatments were tested by ANOVA and comparisons of means using Least Significant Difference $(L S D)$ test, at $p=0.05$. The means and standard deviations $( \pm S D)$ of five replications are reported. Pearson's simple correlation coefficient $(r)$ was also calculated between the heavy metal content indicated in the soil with the level of significance set at $p<0.001$, $p<0.01$ and $p<0.05$. 


\section{RESULTS AND DISCUSSION}

The content of macroelements in the biomass of plants is subjected to specific changes which can be affected by the heavy metal content of soil. The research of other authors, including COLLIN et al. [2014], Kabata-Pendias, Pendias [2001], WYSZKOWSKI, RADZIEMSKA [2010; 2013] and LEMBERKOVICS et al. [2002], reveals that trace elements have a strong and varied influence on the content of macroelements in plants, which was confirmed by our studies. The analysis of results shows that the content of phosphorous $(\mathrm{P})$, sodium $(\mathrm{Na})$, potassium $(\mathrm{K})$, calcium $(\mathrm{Ca})$, magnesium $(\mathrm{Mg})$, and nitrogen $(\mathrm{N})$ in the Indian mustard is influenced by the dose of copper, as well as the addition of zero-valent iron and lignite.

In the control series (no additives), the differences in phosphorus content were positively correlated with the increasing doses of copper (Fig. 3). Indian mustard from this experiment was characterized by phosphorus concentrations ranging from 1.61 to 2.55 $\mathrm{g} \cdot \mathrm{kg}^{-1}$. Soil contamination at $600 \mathrm{mg} \mathrm{Cu} \cdot \mathrm{kg}^{-1}$ of soil led to the highest increase in the phosphorus content of Indian mustard. The application of zero-valent iron (ZVI) had a positive influence on the average phosphorus content of Indian mustard. This reactive material has high surface reactivity, and the introduction of zero-valent iron (ZVI) could shift the redox condition of the local environment and affect the oxygen release rate of plant roots [KIRSCHLING et al. 2010; ZHANG 2003]. The opposite situation was observed in the case of adding lignite, which had an adverse effect causing the average phosphorus content to decrease in the analyzed plant in relation to plants in the control group. The addition of a ZVI/lignite mixture, which caused a $13 \%$ increase in the average content of the above-mentioned element in Indian mustard as compared to the control series, was shown to be the most successful among the assortment of reactive material added to the soil. The results are in agreement with the research of KALEMBASA and WYSOKIŃSKI [2002], in which the addition of brown coal ash caused a de-

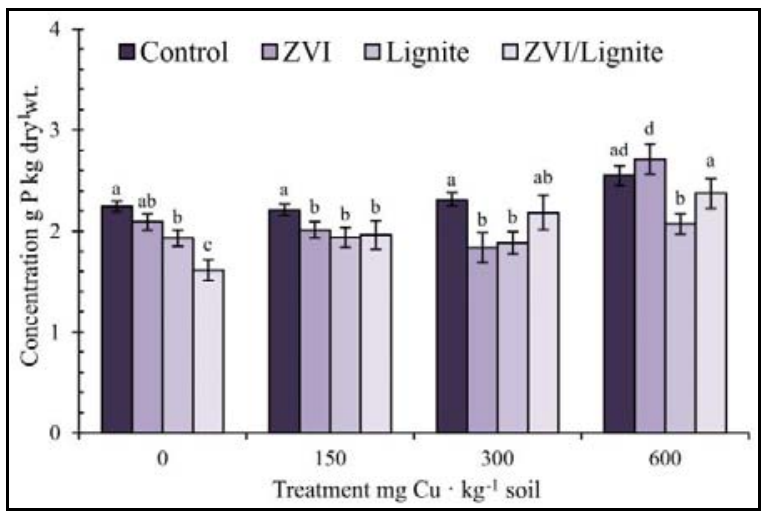

Fig. 3. Effect of copper $(\mathrm{Cu})$ contamination on phosphorus (P) content in Indian mustard ( $\mathrm{g} \cdot \mathrm{kg}^{-1}$ dry mass); mean $\pm S D$, $n=3$; columns marked with different letter indicate significant differences between members of the same set (Tukey test, $p<0.05$ ); source: own study crease in the contents of phosphorus in plants. Our earlier investigation showed that the application of mineral reactive materials to Ni-contaminated soil led to a positive influence on the average phosphorus content of maize [RADZIEMSKA et al. 2013].

The contamination of soil with copper, as well as the application of zero-valent iron (ZVI) and lignite, had a significant effect on the content of potassium in Indian mustard (Fig. 4). Indian mustard from the present experiment was characterized by potassium concentrations ranging from 13.27 to $16.88 \mathrm{~g} \cdot \mathrm{kg}^{-1}$. In the control series (without additives), a positive correlation between the potassium content and the increasing contamination of soil with $\mathrm{Cu}$ occurred. Zero-valent iron (ZVI) had a positive effect on the storage of potassium in the above-ground parts of Indian mustard, which was especially evident in the group of plants with the lowest dose of copper (150 and $300 \mathrm{mg} \cdot \mathrm{kg}^{-1}$ soil). When compared to the control series, zerovalent iron (ZVI) was shown to have the most beneficial effect on the average potassium content in the analyzed plant. Lignite as well as the ZVI/lignite mixture also had a positive effect, although not as pronounced. LESZCZYŃSKA and KWIATKOWSKA-MALINA [2011] reported data revealing that potassium contents in the roots of rye significantly decreased in comparison with the control object as a result of adding lignite. According to KOZERA et al. [2006], copper may decrease potassium content in potato tubers.

Calcium has been found to impede the negative effects of abiotic stress through the regulation of water relations and antioxidant metabolism [ZORRIG et al. 2012]. According to KABATA-PENDIAS and PENDIAS [2001], there is an antagonism between copper and calcium. Calcium concentrations of Indian mustard in the above experiment ranged from 4.96 to 7.05 $\mathrm{g} \cdot \mathrm{kg}^{-1}$. In the present study, calcium content in the Indian mustard was significantly influenced by the dose of copper as well as the reactive materials added to the soil (Fig. 5). Calcium content in plants from the control group, i.e. without the addition of zero-valent iron (ZVI) or lignite, was positively correlated with

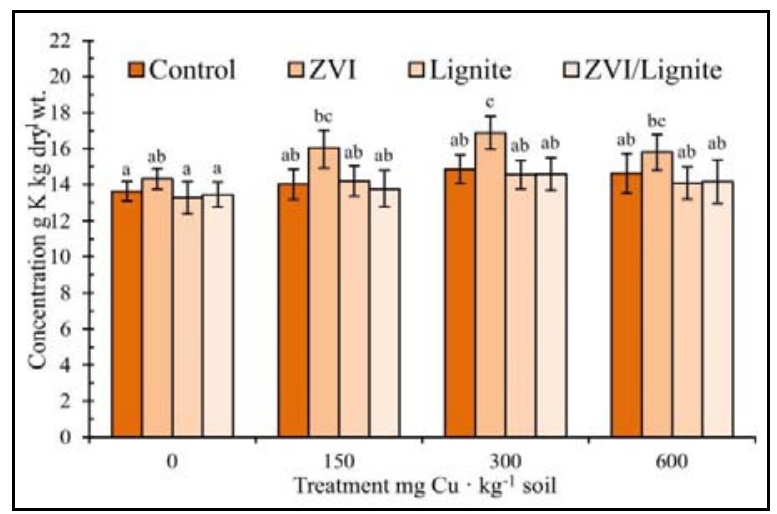

Fig. 4. Effect of copper $(\mathrm{Cu})$ contamination on potassium (K) content in Indian mustard ( $\mathrm{g} \cdot \mathrm{kg}^{-1}$ dry mass); mean \pm $S D, n=3$; columns marked with different letter indicate significant differences between members of the same set (Tukey test, $p<0.05$ ); source: own study 


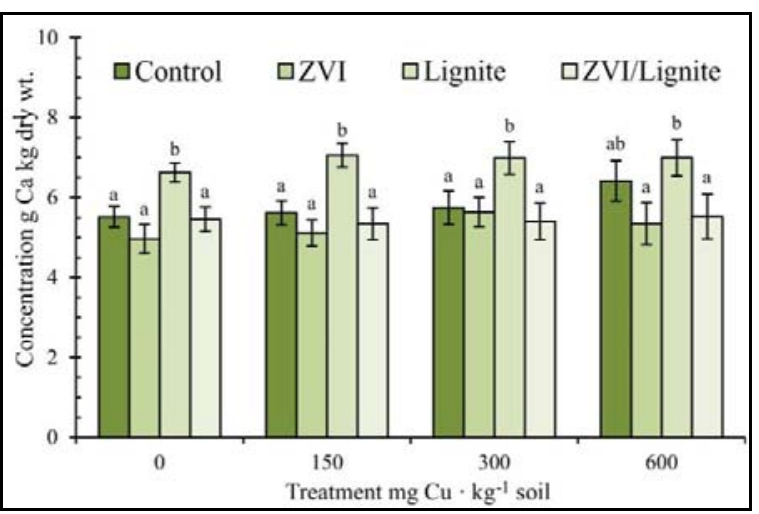

Fig. 5. Effect of copper $(\mathrm{Cu})$ contamination on calcium $(\mathrm{Ca})$ content in Indian mustard ( $\mathrm{g} \cdot \mathrm{kg}^{-1}$ dry mass); mean $\pm S D$, $n=3$; columns marked with different letter indicate significant differences between members of the same set (Tukey test, $p<0.05$ ); source: own study

increasing doses of copper. Soil contamination at 600 $\mathrm{mg} \mathrm{Cu} \cdot \mathrm{kg}^{-1}$ of soil led to the highest increase in calcium content in the analyzed plant. From the analyzed substances neutralizing the effects of copper contamination, the application of lignite was shown to be the most effective, resulting in a $19 \%$ increase in the average calcium content when compared to the control crop. LESZCZYŃSKA and KWIATKOWSKA-MALINA [2011] demonstrated that the addition of lignite to soil causes a higher content of calcium in all parts of rye.

Zero-valent iron (ZVI) and lignite, as well as increasing doses of copper significantly influenced the sodium content of Indian mustard (Fig. 6). The aboveground parts of Indian mustard from the present experiment had sodium concentrations ranging from 1.98 to $2.39 \mathrm{~g} \cdot \mathrm{kg}^{-1}$. Applying copper to soil contributed to increased levels of sodium in plants as compared to the control series - without additives. Crops in the study group without reactive materials, exposed to copper doses of 150 and $300 \mathrm{mg} \cdot \mathrm{kg}^{-1}$ soil were found to have the highest sodium content in their aboveground parts. The addition of zero-valent iron (ZVI) with lignite (ZVI/lignite), which caused a $9 \%$ increase in the average content of the above-mentioned element in Indian mustard as compared to the control series, was shown to be the most successful from the assortment of reactive materials added to the soil. An analogical situation was observed in the case of adding zero-valent iron (ZVI), and lignite, although their influence was weaker. Data presented by LESZCZYŃSKA and KWIATKOWSKA-MALINA [2011] showed that organic matter from different sources did not have an effect on the content of sodium in some parts of rye in variants of soil contaminated with, or without the addition of heavy metals. Indian mustard from the present experiment had sodium concentrations ranging from 4.96 to $7.05 \mathrm{~g} \cdot \mathrm{kg}^{-1}$.

Magnesium has a number of key functions in plants. Moreover, the uptake of $\mathrm{Mg}$ is strongly influenced by the availability of other cations, i.e. $\mathrm{Ca}, \mathrm{K}$, and $\mathrm{NH}_{4}^{+}$[RÖMHELD, KIRKBY 2007]. Magnesium content in Indian mustard was influenced by the dose

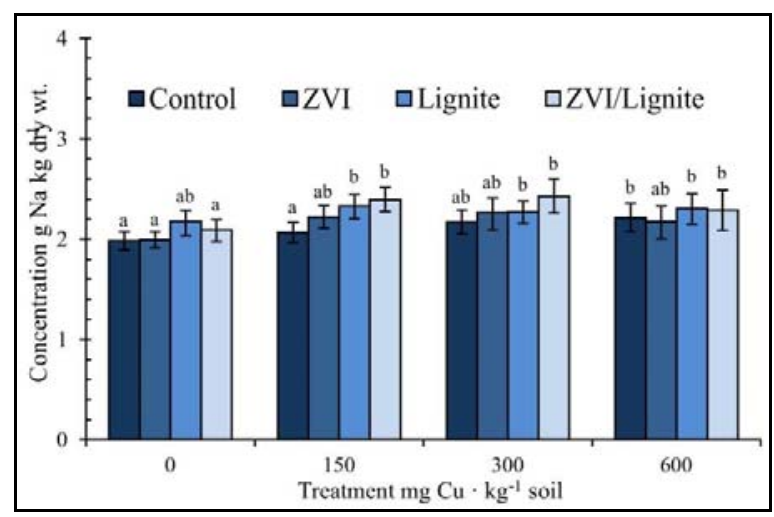

Fig. 6. Effect of copper $(\mathrm{Cu})$ contamination on sodium $(\mathrm{Na})$ content in Indian mustard ( $\mathrm{g} \cdot \mathrm{kg}^{-1}$ dry mass); mean $\pm S D$, $n=3$; columns marked with different letter indicate significant differences between members of the same set (Tukey test, $p<0.05$ ); source: own study

of copper, as well as the addition of reactive materials (Fig. 7). Indian mustard from the present experiment was found to have magnesium concentrations ranging from 0.91 to $1.25 \mathrm{~g} \cdot \mathrm{kg}^{-1}$. Crops in the study group without reactive materials and exposed to a copper dose of $600 \mathrm{mg} \cdot \mathrm{kg}^{-1}$ soil were found to have the highest magnesium content in their above-ground parts. The application of zero-valent iron (ZVI) and lignite had a positive influence on the average magnesium content in the above-ground parts of Indian mustard. When compared to the control series, lignite was shown to have the most beneficial effect on magnesium content in the analyzed plant. Zero valent-iron (ZVI), as well as mixture of ZVI and lignite also had a positive effect, although not as pronounced.

An analysis of the results showed that the content of nitrogen in the Indian mustard was influenced by the dose of copper, as well as the addition of zero valent-iron (ZVI) and lignite (Fig. 8). Indian mustard in the present experiment had nitrogen concentrations ranging from 9.34 to $18.30 \mathrm{~g} \cdot \mathrm{kg}^{-1}$. Nitrogen content in plants from the control group (without the addition of reactive materials) was positively correlated with in-

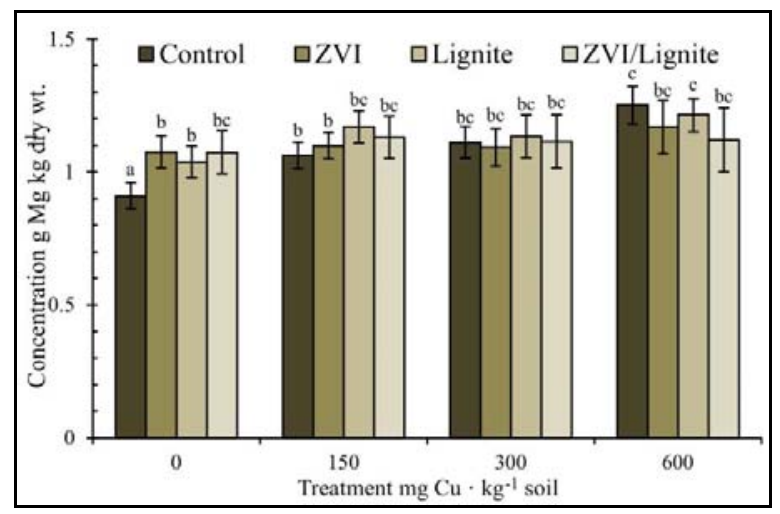

Fig. 7. Effect of copper $(\mathrm{Cu})$ contamination on magnesium $(\mathrm{Mg})$ content in Indian mustard $\left(\mathrm{g} \cdot \mathrm{kg}^{-1}\right.$ dry mass); mean \pm $S D, n=3$; columns marked with different letter indicate significant differences between members of the same set (Tukey test, $p<0.05$ ); source: own study 


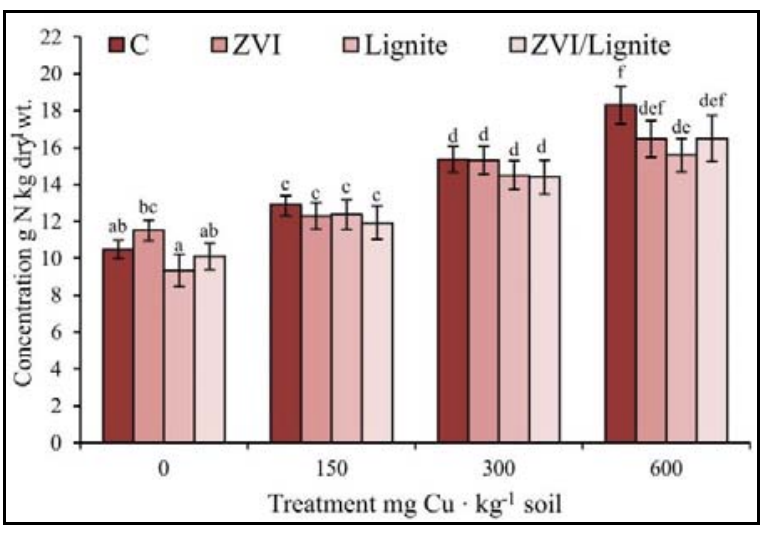

Fig. 8. Effect of copper $(\mathrm{Cu})$ contamination on nitrogen $(\mathrm{N})$ content in Indian mustard ( $\mathrm{g} \cdot \mathrm{kg}^{-1}$ dry mass); mean $\pm S D$, $n=3$; columns marked with different letter indicate significant differences between members of the same set (Tukey test, $p<0.05$ ); source: own study

creasing doses of cooper. In objects contaminated with 300 and $600 \mathrm{mg} \mathrm{Cu} \cdot \mathrm{kg}^{-1}$, the content of the analyzed element was higher (44\% and $61 \%$ ) in relation to objects which had not been contaminated. From the analyzed reactive materials, the application of lignite was shown to be the most effective, resulting in a $9 \%$ decrease in the average nitrogen content when compared to the control crop. The application of organic matter to soil usually leads to a higher accumulation of nitrogen in plants [EGHBALL et al. 2002]. Lignite can be a good source of supplementing soils with organic matter. This substance delivers material with a high degree of humification and is relatively resistant to mineralization [LOPAREVA-POHU et al. 2011]. In regards to soil enrichment with organic matter, increased contents of nitrogen have been observed in the organs of many plant species, i.e. spring barley and maize [WYSZKOWSKI, RADZIEMSKA 2010], and triticale grain and straw [CIEĆKO et al. 2001]. In an experiment conducted by ELEIWA [2004], copper strongly affected nitrogen assimilation in wheat and lupine.

\section{CONCLUSIONS}

The reactive materials applied in the experiment, i.e. zero-valent iron (ZVI) and lignite, significantly shaped the content of phosphorus, calcium, sodium, magnesium, potassium, and nitrogen in the aboveground parts of Indian mustard cv. Małopolska. The average accumulation of macronutrients in Indian mustard grown in $\mathrm{Cu}$-contaminated soil was found to follow the decreasing order of $\mathrm{Mg}>\mathrm{Na}>\mathrm{P}>\mathrm{Ca}>\mathrm{K}$ $>\mathrm{N}$.

Soil contamination at $600 \mathrm{mg} \mathrm{Cu} \cdot \mathrm{kg}^{-1}$ of soil led to the highest increase in phosphorous, magnesium, nitrogen, and calcium content in Indian mustard. The application of zero-valent iron (ZVI) had a positive influence on the average phosphorus and potassium content of this plant species. Moreover, the application of zero-valent iron (ZVI) and lignite had a posi- tive influence on the average magnesium and calcium content in the above-ground parts of the studied plant. In the non-amended treatments (no reactive materials), the increasing rates of copper had an explicitly positive effect on the content of calcium in Indian mustard. From the analyzed reactive materials, the application of lignite was shown to be the most effective, resulting in a decrease in the average nitrogen and calcium content as compared to the control crop.

\section{REFERENCES}

AlOwItZ M., Scherer M. 2002. Kinetic of nitrate, nitrite and $\mathrm{Cr}(\mathrm{VI})$ reduction by iron metal. Environmental Science and Technology. Vol. 36 p. 299-306.

BREMNER J.M. 1965. Total nitrogen. In: Methods of soil analysis. Part 2. Chemical and microbiological properties. Eds C.A. Black, D.D. Evans, L.E. Ensminger, J.L. White, F.E. Clark. Madison, Winscousin. American Society of Agronomy. Agronomy. No. 9 p. 1149-1178.

Burghardt D., SimON E., KNÖLler K., KASSAhun A. 2007. Immobilization of uranium and arsenic by injectable iron and hydrogen stimulated autotrophic sulphate reduction. Journal of Contaminant Hydrology. Vol. 94 p. 305-314.

Calderon B., Fullana A. 2015. Heavy metal release due to aging effect during zero valent iron nanoparticles remediation. Water Research. Vol. 83 p. 1-9.

CAVELL A.J. 1955. The colorimetric determination of phosphorous in plant materials. Journal of the Science of Food and Agriculture. Vol. 6. Iss. 8 p. 479-481.

CiećKo Z., WyszKowsKi M., KRAJEWSKI W., ZABIELSKA J. 2001. Effect of organic matter and liming on the reduction of cadmium uptake from soil by triticale and spring oilseed rape. Science of the Total Environment. Vol. 281. Iss. 1-3 p. 37-45.

Collin B., Doelsch E., Keller C., Cazevieille P., Tella M., Chaurand P., Panfili F., Hazemann J.L., Meunier J.D. 2014. Evidence of sulfur-bound reduced copper in bamboo exposed to high silicon and copper concentrations. Environmental Pollution. Vol. 187 p. 22-30.

Cundy A.B., Hopkinson L., WhitBy R.L. 2008. Use of iron - based technologies in Contaminated land and groundwater remediation: a review. Science of the Total Environment. Vol. 400 p. 42-51.

Eghball B., Wienhold B.J., Gilley J.E., Eigenberg R.A. 2002. Nutrient management in the United States: a joint symposium. Journal of Soil and Water Conservation. Vol. 57. Iss. 6 p. $470-473$.

ElEIWA M.M.E. 2004. Response of lupine and wheat to soil contamination with heavy metals. Egyptian Journal of Soil Science. Vol. 44. Iss. 1 p. 1-17.

FJordbøge A.S., RiIs C., Christensen A.G., KJeldsen P. 2012. ZVI-Clay remediation of a chlorinated solvent source zone, Skuldelev, Denmark: 1. Site description and contaminant source mass reduction. Journal of Contaminant Hydrology. Vol. 140-141 p. 56-66.

FRONCZYK J., PAWLUK K. 2014. Hydraulic performance of zero-valent iron and nano-sized zero-valent iron permeable reactive barriers - laboratory test. Annals of Warsaw University of Life Sciences-SGGW. Land Reclamation. Vol. 46. Iss. 1 p. 33-42.

Hwang Y., Salatas A., Mines P.D., JakobSEn M.H., ANDERSEN H.R. 2016. Graduated characterization method using a multi-well microplate for reducing reactivity of 
nanoscale zero valent iron materials. Applied Catalysis B: Environmental. Vol. 181 p. 314-320.

Jin J., Sun K., Wang Z., Han L., Pan Z., Wu F., LiU X., ZHAO Y., XING B. 2015. Characterization and phthalate esters sorption of organic matter fractions isolated from soils and sediments. Environmental Pollution. Vol. 206 p. 24-31.

Kabata-Pendias A., Pendias H. 2001. Trace elements in soils and plants. 3rd ed. Boca Raton, London, New York, Washington DC. CRC Press LLC. ISBN 0-84931575-1 pp. 413.

KAlEMBASA S., WysOKiŃSKi A. 2002. Wpływ nawożenia mieszaniną osadów ściekowych $\mathrm{z}$ popiołem $\mathrm{z}$ węgla brunatnego lub $\mathrm{CaO}$ na plon i skład chemiczny roślin. Cz. II. Zawartość wybranych makroelementów [The influence of fertilization with sewage sludges mixed with the brown coal or with $\mathrm{CaO}$ on the yield and chemical composition of the plants. Part II. The content of selected micronutrients in plants]. Zeszyty Problemowe Postępów Nauk Rolniczych. Z. 482 p. 257-263.

Kirschling T.L., Gregory K.B., Minkley E.G., Lowry G.V., TILTON R.D. 2010. Impact of nanoscale zero valent iron on geochemistry and microbial populations in trichloroethylene contaminated aquifer materials. Environmental Science and Technology. Vol. 44 p. 34743480.

KLuTE A. 1996. Methods of soil analysis. Madison. American Society of Agronomy. Agronomy Monograph 9.

Kozera W., NowaK K., MajcherczaK E., BarczaK B. 2006. Effect of foliar fertilization with micronutrients on content of macronutrients in potato tubers. Journal of Elementology. Vol. 11. Iss. 1 p. 29-34.

KwiatKowsKa J., SokoŁowska Z., MaciejewsKa A. 2006. Selected physical and chemical properties for evaluating brown coals used for soil reclamation. International Agrophysics. Vol. 20. Iss. 2 p. 121-128.

Lemberkovics E., CzinNer E., Szentmihalyi K., Balazs A., Szoke E. 2002. Comparative evaluation of Helichrysi flos herbal extracts as dietary sources of plant polyphenols, and macro- and microelements. Food Chemistry. Vol. 78 p. 119-127.

LESZCZYŃSKA D., KWIATKOWSKA-MALINA J. 2011. Effect of organic matter from various sources on yield and quality of plant on soils contaminated with heavy metals. Ecological Chemistry and Engineering S. Vol. 18. Iss. 4 p. 501-507.

Lopareva-Pohu A.,Verdin A., Garçon G., LounÈs-Hadj Sahraoui A., Pourrut B., Debiane D., Waterlot C., Laruelle F., Bidar G., Douay F., Shirali P. 2011. Influence of fly ash aided phytostabilisation of $\mathrm{Pb}, \mathrm{Cd}$ and $\mathrm{Zn}$ highly contaminated soils on Lolium perenne and Trifolium repens metal transfer and physiological stress. Environmental Pollution. Vol. 159. Iss. 6 p. 1721-1729.
MASCIANGIOLI T., ZhANG W. 2003. Environmental nanotechnology. Potential and pitfalls. Environmental Science and Technology. Vol. 37 p. 102-108.

MoceK A., DrzymaŁA S. 2010. Geneza, analiza i klasyfikacja gleb [Genesis, analysis and soil classification]. Poznań. Wydaw. UP. ISBN 978-83-71605-86-4 pp. 420.

Puls W., Paul C.J., Powell R.M. 1999. The application of in situ permeable reactive (zero-valent iron) barrier technology for the remediation of chromate - contaminated ground water: a field test. Applied Geochemistry. Vol. 14 p. 989-1000.

RADZIEMSKA M., MAZUR Z., JEZNACH J. 2013. Influence of applying halloysite and zeolite to soil contaminated with nickel on the content of selected elements in maize (Zea mays L.). Chemical Engineering Transactions. Vol. 32 p. 301-306.

RÖMHELD V., KIRKBY E.A. 2007. Magnesium functions in crop nutrition and yield. Proceedings of a Conference in Cambridge (7th Dec. 2007). T. 616. Colchester. IFS p. $151-171$.

Santana N.A., Ferreira P.A.A., Soriani H.H., Brunetto G., Nicoloso F.T., ANTONIOlli Z.I., JACQUES R.J.S. 2015. Interaction between arbuscular mycorrhizal fungi and vermicompost on copper phytoremediation in a sandy soil. Applied Soil Ecology. Vol. 96 p. 172-182.

SZYSZKO E. 1982. Instrumental analytical method. Warsaw. PZWL pp. 623.

WYSZKOWSKI M., RADZIEMSKA M. 2010. Effects of chromium (III and VI) on spring barley and maize biomass yield and content of nitrogen compounds. Journal of Toxicology and Environmental Health. Part A. Vol. 73. Iss. $17-18$ p. 1274-1282.

WYSZKOWSKI M., RADZIEMSKA M. 2013. Influence of chromium (III) and (VI) on the concentration of mineral elements in oat (Avena sativa L.). Fresenius Environmental Bulletin. Vol. 22. Iss. 4 p. 979-986.

ZaheEr I.E., Ali S., RizWAn M., FARID M., SHAKoOr M.B., Gill R.A., NAJeeb U., IQBAL N., AhMAD R. 2015. Citric acid assisted phytoremediation of copper by Brassica napus L. Ecotoxicology and Environmental Safety. Vol. 120 p. $310-317$.

ZHANG W. 2003. Nanoscale iron particles for environmental remediation: An overview. Journal of Nanoparticle Research. Vol. 5 p. 323-332.

Zorrig W., Shahzad Z., Abdelly C., Berthomieu P. 2012. Calcium enhances cadmium tolerance and decreases cadmium accumulation in lettuce (Lactuca sativa). African Journal of Biotechnology. Vol. 11 p. 8441-8448.

XU I., ZHAO D. 2007. Reductive immobilization of chromate in water and soil using stabilized iron nanoparticles. Water Research. Vol. 41. Iss. 10 p. 2101-2108. 
Maja RADZIEMSKA, Jerzy JEZNACH, Zbigniew MAZUR, Joanna FRONCZYK, Ayla BILGIN

Ocena wpływu materiałów reaktywnych na zawartość wybranych pierwiastków w gorczycy sarepskiej uprawianej na glebie zanieczyszczonej miedzią

\section{STRESZCZENIE}

Slowa kluczowe: gorczyca sarepska, wegiel brunatny, zanieczyszczenie gleby, żelazo elementarne

Zakres badań obejmował określenie wpływu zanieczyszczenia gleby miedzią $(0,80,150,300$ i $600 \mathrm{mg}$ $\mathrm{Cu} \cdot \mathrm{kg}^{-1}$ ) oraz dodatku żelaza elementarnego (ZVI) i węgla brunatnego na zawartość wybranych makroelementów w gorczycy sarepskiej (Brassica juncea (L.) Czern.). Średnia zawartość analizowanych makroskładników w gorczycy rosnącej na glebie zanieczyszczonej miedzią kształtowała się następująco: $\mathrm{Mg}>\mathrm{Na}>\mathrm{P}>\mathrm{Ca}>\mathrm{K}>$ $\mathrm{N}$. Gleba zanieczyszczona w dawce $600 \mathrm{mg} \mathrm{Cu} \cdot \mathrm{kg}^{-1}$ spowodowała zwiększenie zawartości $\mathrm{P}, \mathrm{Mg}, \mathrm{N}$ i Ca. Dodatek żelaza elementarnego (ZVI) wywarł pozytywny wpływ na średnią zawartość fosforu i potasu w Brassica juncea. Ponadto ZVI i węgiel brunatny wpływały pozytywnie na średnią zawartość Mg i Ca w częściach nadziemnych analizowanej rośliny. Spośród dodawanych do gleby analizowanych materiałów reaktywnych węgiel brunatny spowodował największy wzrost zawartości azotu i wapnia w częściach nadziemnych analizowanej rośliny. Zawartość wapnia w roślinach rosnących w grupie kontrolnej (bez dodatku żelaza elementarnego i węgla brunatnego) była dodatnio skorelowana ze wrastającym zanieczyszczeniem gleby miedzią. 